\title{
Conversion of a Monodentate Amidinate-Germylene Ligand into Chelating Imine-Germanate Ligands (on Mononuclear Manganese Complexes)
}

\author{
Javier A. Cabeza, ${ }^{* \dagger}$ Pablo García-Álvarez, ${ }^{* \dagger}{ }^{\dagger}$ Enrique Pérez-Carreño, ${ }^{\dagger}$ and Diego Polo ${ }^{\dagger}$ \\ †Departamento de Química Orgánica e Inorgánica-IUQOEM, Universidad de Oviedo-CSIC, E- \\ 33071 Oviedo, Spain
}

†Departamento de Química Física y Analítica, Universidad de Oviedo, E-33071 Oviedo, Spain

\begin{abstract}
The unprecedented transformation of a terminal 2-electron-donor amidinategermylene ligand into a chelating 3-electron-donor $\kappa^{2}-N, G e$-imine-germanate ligand has been achieved by treating the manganese amidinate-germylene complex $\left[\operatorname{MnBr}\left\{\mathrm{Ge}\left({ }^{i} \mathrm{Pr}_{2} \text { bzam }\right)^{t} \mathrm{Bu}\right\}(\mathrm{CO})_{4}\right]\left(\mathbf{1} ;{ }^{i} \operatorname{Pr}_{2}\right.$ bzam $=N, N$ '-bis $($ iso-propyl)benzamidinate $)$ with LiMe or $\mathrm{Ag}\left[\mathrm{BF}_{4}\right]$. In these reactions, which afford $\left[\mathrm{Mn}\left\{\kappa^{2} G e, N-\mathrm{GeMe}\left({ }^{i} \operatorname{Pr}_{2} \mathrm{bzam}\right)^{t} \mathrm{Bu}\right\}(\mathrm{CO})_{4}\right](2)$ and $\left[\mathrm{Mn}\left\{\kappa^{2} G e, N-\mathrm{GeF}\left({ }^{i} \operatorname{Pr}_{2} \mathrm{bzam}\right)^{t} \mathrm{Bu}\right\}(\mathrm{CO})_{4}\right](3)$, respectively, the anionic nucleophile, $\mathrm{Me}^{-}$or $\mathrm{F}^{-}$, ends on the Ge atom while an arm of the amidinate fragment migrates from the Ge atom to the $\mathrm{Mn}$ atom. In contrast, the reaction of 1 with AgOTf (OTf = triflate) leads to $\left[\mathrm{Mn}(\mathrm{OTf})\left\{\mathrm{Ge}\left({ }^{i} \mathrm{Pr}_{2} \text { bzam }\right)^{t} \mathrm{Bu}\right\}(\mathrm{CO})_{4}\right](4)$, which maintains intact the amidinate-germylene ligand. Complex 4 is very moisture-sensitive, leading to $\left[\mathrm{Mn}_{2}\left\{\mu-\kappa^{4} G e_{2}, O_{2}-\mathrm{Ge}_{2}{ }_{2} \mathrm{Bu}_{2}(\mathrm{OH})_{2} \mathrm{O}\right\}(\mathrm{CO})_{8}\right]$ (5) and $\left[{ }^{i} \operatorname{Pr}_{2}\right.$ bzamH $\left.{ }_{2}\right]$ OTf (6) in wet solvents. In 5, a novel digermanate(II) ligand, $\left[{ }^{t} \mathrm{Bu}(\mathrm{OH}) \mathrm{GeOGe}(\mathrm{OH})^{t} \mathrm{Bu}\right]^{2-}$, doubly bridges two $\mathrm{Mn}(\mathrm{CO})_{4}$ units. The structures of $\mathbf{1}-\mathbf{6}$ have been characterized by spectroscopic (IR, NMR) and single crystal X-ray diffraction methods.
\end{abstract}




\section{INTRODUCTION}

The coordination chemistry of heavier carbene analogues (also known as heavier tetrylenes, HTs) stabilized by amidinate groups has experienced an exponential growth in the last few years. ${ }^{1-8}$ They form stable complexes with almost all of the elements of the transition metal (TM) series and, importantly, some of their TM complexes have already been successfully tested as catalyst precursors for useful reactions, ${ }^{\text {a }}$ such as Sonogashira cross-couplings, ${ }^{3 a}$ ketone hidrosilylations ${ }^{3 \mathrm{~b}}$ cross-coupling reactions of aryl halides with organometallic zinc and Grignard reagents, ${ }^{3 \mathrm{f}}[2+2+2]$ cycloadditions,${ }^{4 \mathrm{a}}$ and arene $\mathrm{C}-\mathrm{H}$ borylations. ${ }^{4 \mathrm{~b}}$

The vast majority of the hitherto reported amidinate-HT-TM complexes have their amidinate-HTs behaving as terminal ligands attached to the TM atom through the corresponding group-14 donor atom and this situation is maintained in the products of their reactions. We have recently discovered a remarkable exception to this spectator behavior of amidinate-HT ligands, since the germylene $\operatorname{Ge}\left({ }^{i} \operatorname{Pr}_{2}\right.$ bzam $)(\mathrm{HMDS})\left[{ }^{i} \operatorname{Pr}_{2}\right.$ bzam $=N, N^{\prime}$-bis(iso-propyl)benzamidinate; HMDS $\left.=\mathrm{N}\left(\mathrm{SiMe}_{3}\right)_{2}\right]$, which is equipped with just one lone pair of electrons on the Ge atom, can be transformed into a bridging 4-electron-donor $\kappa^{2}-N, G e$-imine-germylene ligand when treated with $\left[\mathrm{Co}_{2}(\mathrm{CO})_{8}\right]^{2 \mathrm{~b}}$ and $\left[\mathrm{Ru}_{3}(\mathrm{CO})_{12}\right]^{2 \mathrm{c}, 3 \mathrm{~g}}$ (Scheme 1). Until then, such a bidentate coordination

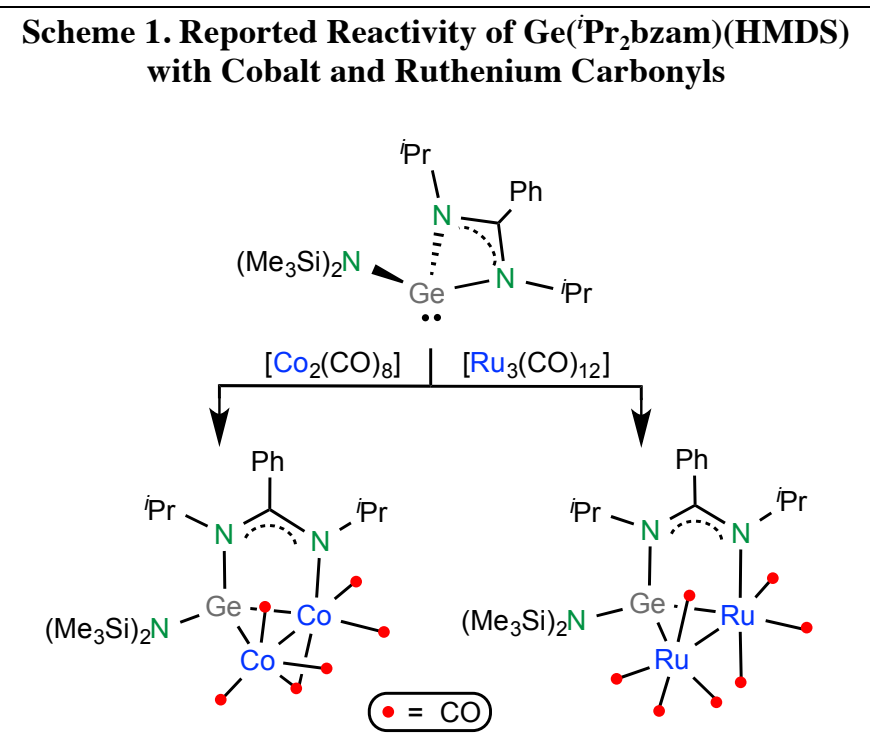

mode, which implies the opening of the germylene $\mathrm{GeN}_{2} \mathrm{C}$ ring and the subsequent coordination of one of the arms of the amidinate fragment to the TM, was unknown for amidinate-HT ligands. In a related work, Tacke et al. have described the opposite ligand behavior, since the 
bis(amidinate)-silylene $\operatorname{Si}\left({ }^{i} \operatorname{Pr}_{2} \text { bzam }\right)_{2}$, which contains one chelating and one terminal amidinate, closes its pendant imine arm towards the silicon atom upon coordination of the latter to a tungsten centre. ${ }^{4 \mathrm{f}}$

In this contribution, we report (a) the first amidinate-germylene derivatives of manganese (the only amidinate-HT-Mn complexes hitherto known are silylene derivatives ${ }^{4 \mathrm{~g}, 5}$ ), (b) the unprecedented observation that a terminal 2-electron-donor amidinate-germylene ligand can be converted into chelating 3-electron-donor $\kappa^{2} N, G e$-imine-germanate ligands, and (c) a hydrolysis reaction that leads to a neutral dimanganese(I) derivative that contains the novel digermanate(II) $\left[{ }^{t} \mathrm{Bu}(\mathrm{OH}) \mathrm{GeOGe}(\mathrm{OH})^{t} \mathrm{Bu}\right]^{2-}$ as a bridging $\kappa^{4} G e_{2}, O_{2}$-ligand.

\section{RESULTS AND DISCUSSION}

The manganese(I) amidinate-germylene complex $\left[\operatorname{MnBr}\left\{\mathrm{Ge}\left({ }^{i} \operatorname{Pr}_{2} \text { bzam }\right)^{t} \mathrm{Bu}\right\}(\mathrm{CO})_{4}\right](\mathbf{1})$ was easily prepared by treating $\left[\mathrm{MnBr}(\mathrm{CO})_{5}\right]$ with one equivalent of the germylene $\operatorname{Ge}\left({ }^{i} \operatorname{Pr}_{2} \mathrm{bzam}\right)^{t} \mathrm{Bu}$ at room temperature (toluene, $10 \mathrm{~min}$ ). An X-ray diffraction (XRD) study (Figure 1) confirmed the

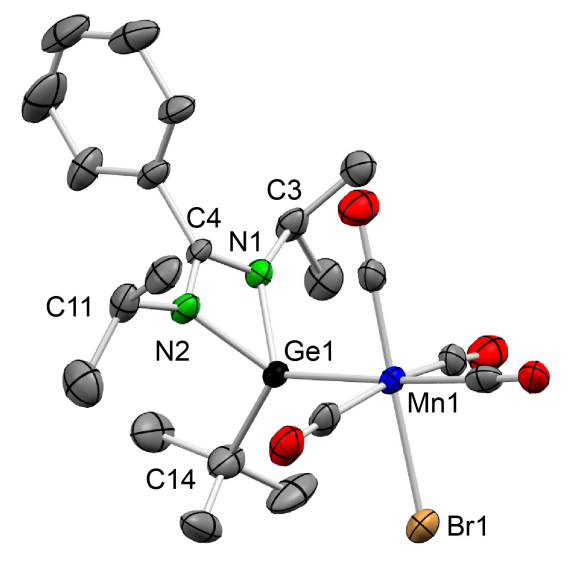

Figure 1. XRD molecular structure of 1 (40 \% displacement ellipsoids; $\mathrm{H}$ atoms omitted for clarity; only one of the four symmetry-independent but analogous molecules found in the asymmetric unit is shown). Selected interatomic distances $(\AA)$ : Mn1-Ge1 2.398(1), Ge1-C14 1.994(9), Ge1-N1 1.988(6), Ge1-N2 1.998(7), N1-C3 1.46(1), N1-C4 1.30(1), N2-C4 1.34(1), N2-C11 1.46(1). The $\mathrm{Mn}-\mathrm{Br}$ distance is not given because the $\mathrm{Br}$ atom and one $\mathrm{CO}$ ligand are involved in exchange positional disorder.

cis arrangement of its $\mathrm{Br}$ and $\mathrm{Ge}\left({ }^{i} \mathrm{Pr}_{2}\right.$ bzam) ${ }^{t} \mathrm{Bu}$ ligands. Its IR (four $\mathrm{v}_{\mathrm{CO}}$ absorptions) and NMR spectra (equivalent iso-propyl groups) are compatible with a molecule having an average $C_{\mathrm{S}}$ 
symmetry, confirming that, in solution at room temperature, there is free rotation about the $\mathrm{Ge}-$ Mn bond.

In a recent paper, Driess, Inoue, and coworkers have reported the opening of a palladium-bound amidinate-silylene $\mathrm{SiNCN}$ ring induced by a hydride shift from $\mathrm{Pd}$ to $\mathrm{Si}$, however, in that case, the amidinate open arm remained uncoordinated. ${ }^{\text {th }}$ That paper prompted us to introduce a hydride into our system, looking for a similar GeNCN ring opening, but, unfortunately, all attempted reactions of complex $\mathbf{1}$ with hydride donors, such as $\mathrm{Na}\left[\mathrm{BH}_{4}\right]$, $\mathrm{K}\left[\mathrm{BH}^{s} \mathrm{Bu}_{3}\right]$, or $\mathrm{Li}\left[\mathrm{BHEt}_{3}\right]$, led to dark suspensions, the ${ }^{1} \mathrm{H}$ NMR spectra of which contained many broad peaks, including various hydride resonances. Due to the air- and moisture-sensitivity of these mixtures they could not be separated by chromatographic methods and they were not further investigated. Additionally, trying to induce a Mn-to-Ge shift of the $\mathrm{Br}$ atom of $\mathbf{1}$, we heated this complex in toluene at $90{ }^{\circ} \mathrm{C}$, but and inseparable mixture was again obtained. These results led us to attempt a replacement of a methyl group for the bromine atom of $\mathbf{1}$, reasoning that a Mn-to-Ge shift of a methyl group could be easier than that of the bromide. The room temperature treatment of a toluene solution of complex 1 with an ethereal solution of LiMe led to a product that was subsequently identified as $\left[\mathrm{Mn}\left\{\kappa^{2} G e, N-\mathrm{GeMe}\left({ }^{i} \operatorname{Pr}_{2} \mathrm{bzam}\right)^{t} \mathrm{Bu}\right\}(\mathrm{CO})_{4}\right](\mathbf{2}$; Scheme 2).

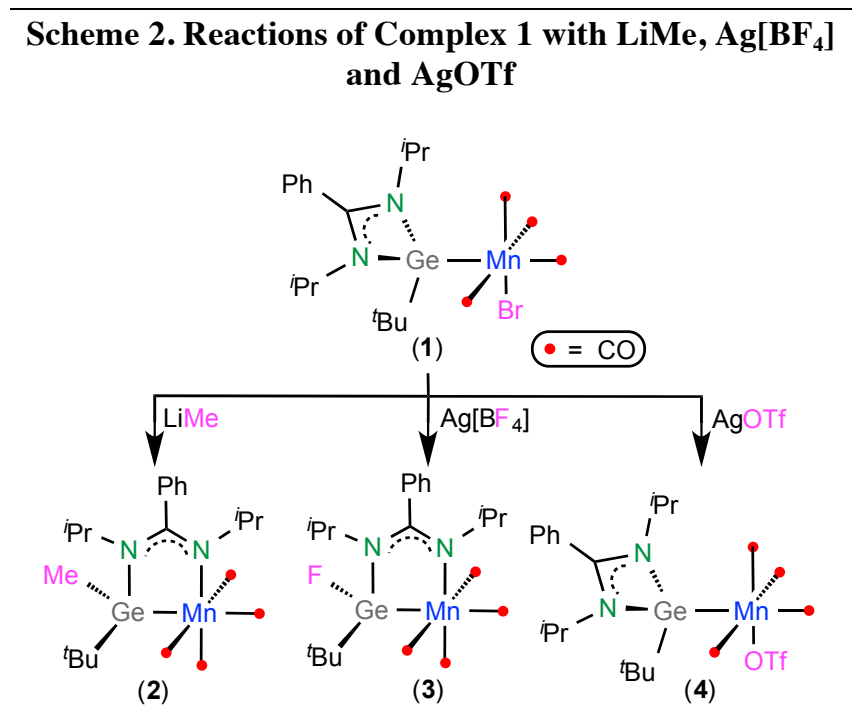

The ${ }^{1} \mathrm{H}$ and ${ }^{13} \mathrm{C}\left\{{ }^{1} \mathrm{H}\right\}$ NMR spectra of 2 , confirmed the incorporation of the methyl group (singlets at $\delta_{\mathrm{H}} 0.96 \mathrm{ppm}$ and $\delta_{\mathrm{C}} 24.6 \mathrm{ppm}$, respectively, in $\mathrm{C}_{6} \mathrm{D}_{6}$ ) but, surprisingly, they also indicated the absence of any symmetry in the molecule. The XRD structure of 2 (Figure 2) 
determined that the molecule is a tetracarbonyl manganese derivative containing a chelating $\kappa^{2} \mathrm{~N}, \mathrm{Ge}$-imine-germanate ligand that formally results from the addition of a $\mathrm{Me}^{-}$group to the Ge atom of 1 , the opening of a Ge-N bond of the GeNCN ring of the original germylene ligand, and the displacement of the bromide group from the Mn atom by the resulting imine arm of the open amidinate fragment.

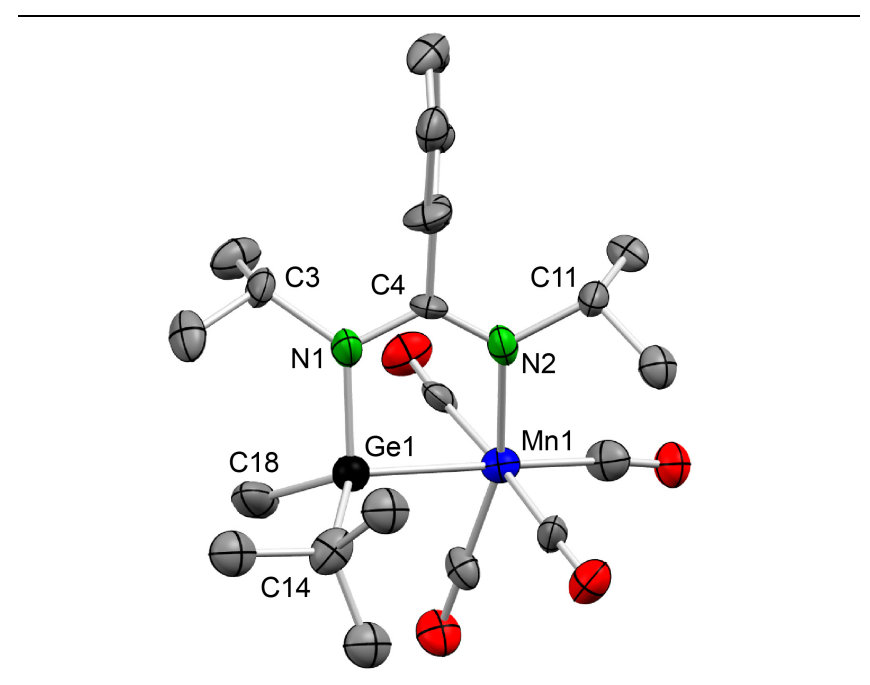

Figure 2. XRD molecular structure of 2 (25\% displacement ellipsoids; $\mathrm{H}$ atoms omitted for clarity). Selected interatomic distances $(\AA)$ : Mn1-Ge1 2.428(5), Mn1-N2 2.12(2), Ge1-C14 1.97(3), Ge1-C18 1.88(3), Ge1-N1 1.91(2), N1-C3 1.55(3), N1-C4 1.37(3), N2-C4 $1.30(3), \mathrm{N} 2-\mathrm{C} 11$ 1.54(3).

We also treated $\left[\mathrm{MnMe}(\mathrm{CO})_{5}\right]$ with $\mathrm{Ge}\left({ }^{i} \mathrm{Pr}_{2} \text { bzam }\right)^{t} \mathrm{Bu}$, but no reaction occurred in toluene at $20{ }^{\circ} \mathrm{C}$ and extensive decomposition was observed when the solution was heated at $90{ }^{\circ} \mathrm{C}$.

Complex 2 contains an anionic chelating 3-electron-donor $\kappa^{2}-N, G e$-imine-germanate ligand, a coordination mode previously unknown for amidinate-HT ligands. Interestingly, a few days prior to the submission of the revised version of this paper, Tacke and coworkers reported the synthesis of group-6 metal carbonyl complexes containing a chelating 4-electron-donor imine-silylene ligand by treating the corresponding metal carbonyl with a bis(guanidinate)silylene that contains one chelating and one terminal guanidinate. ${ }^{9}$ However, in this case, the reaction products do not arise from an insertion of the corresponding group- 6 metal atom into an $\mathrm{Si}-\mathrm{N}$ bond, but from the coordination to the group- 6 metal atom of both the $\mathrm{Si}$ atom and the free $\mathrm{N}$ atom of the pendant (not chelating) guanidinate group of the starting silylene. 
Pursuing our objective of preparing a mononuclear complex containing a chelating 4electron-donor imine-germylene ligand, we reasoned that the simple insertion of the Mn atom of 1 into a $\mathrm{Ge}-\mathrm{N}$ bond of its amidinate-germylene ligand (without adding a nucleophile to the Ge atom) could be facilitated by removing the bromide ligand of $\mathbf{1}$ with a silver salt of a noncoordinating anion. However (and interestingly), the room temperature reaction of complex $\mathbf{1}$ with one equivalent of $\mathrm{Ag}\left[\mathrm{BF}_{4}\right]$ led to a product, $\left[\mathrm{Mn}\left\{\kappa^{2} G e, N-\mathrm{GeF}\left({ }^{i} \operatorname{Pr}_{2} \mathrm{bzam}\right)^{t} \mathrm{Bu}\right\}(\mathrm{CO})_{4}\right](\mathbf{3}$; Scheme 1), whose molecular structure, determined by analytical, spectroscopic (Supporting Information) and XRD methods (Figure 3), is entirely analogous to that of complex 2 but having a fluoride instead of a methyl group on the Ge atom. Therefore, $\left[\mathrm{BF}_{4}\right]^{-}$anion has in this occasion behaved as a source of $\mathrm{F}^{-}$anion, a role that is unusual but not unknown. ${ }^{10}$

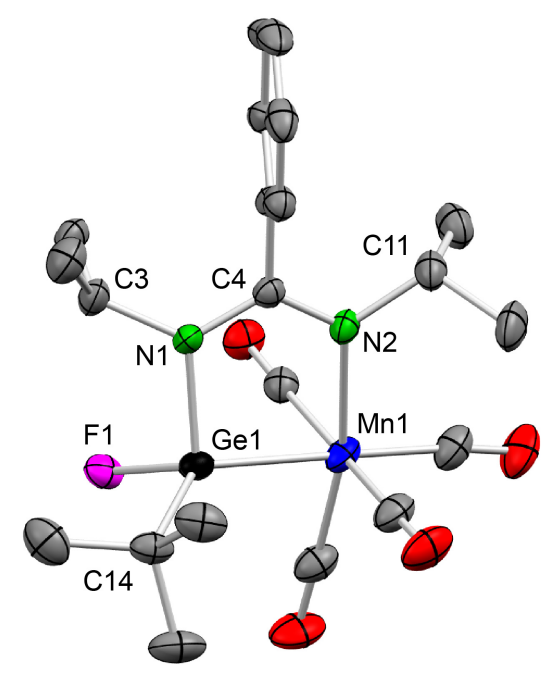

Figure 3. XRD molecular structure of 3 (30\% displacement ellipsoids; $\mathrm{H}$ atoms omitted for clarity). Selected interatomic distances ( $)$ : Mn1-Ge1 2.3647(9), Mn1-N2 2.126(4), Ge1-C14 1.986(5), Ge1-F1 1.776(2), Ge1-N1 1.901(3), N1-C3 1.494(6), N1-C4 1.352(5), N2C4 1.314(6), N2-C11 1.490(6).

With the aim of getting a mechanistic insight into the processes that lead to compounds 2 and 3 , low temperature reactions were monitored by IR spectroscopy ( $v_{\mathrm{CO}}$ region). In both cases, the reagents were initially mixed in toluene at $-80{ }^{\circ} \mathrm{C}$, but, as no reaction was observed, the temperature was slowly raised. In the reaction of $\mathbf{1}$ with LiMe, the $v_{\mathrm{CO}}$ absorptions of the starting material were replaced by those of compound 2 at $c a .0{ }^{\circ} \mathrm{C}$ (no transient species were detected). However, in the reaction of $\mathbf{1}$ with $\mathrm{Ag}\left[\mathrm{BF}_{4}\right]$, the $v_{\mathrm{CO}}$ absorptions of complex $\mathbf{1}$ disappeared at $c a$. 
$-30{ }^{\circ} \mathrm{C}$, being replaced by those of an intermediate complex having a $v_{\mathrm{CO}}$ pattern very similar to that of 1 but with the bands shifted to higher frequencies [2091 (m), 2026 (m), 2002 (vs), 1946 (m) $\left.\mathrm{cm}^{-1}\right]$, as expected for $\left[\mathrm{Mn}\left(\mathrm{BF}_{4}\right)\left\{\mathrm{Ge}\left({ }^{i} \mathrm{Pr}_{2} \mathrm{bzam}\right)^{t} \mathrm{Bu}\right\}(\mathrm{CO})_{4}\right]$. Above $c a .0{ }^{\circ} \mathrm{C}$, the absorptions of this intermediate species were finally transformed into those of complex $\mathbf{3}$. Therefore, the synthesis of compound 3 (and probably also that of 2) begins with the replacement of the $\mathrm{Br}^{-}$ anion of $\mathbf{1}$ by the corresponding nucleophile. This is in complete agreement with the results of a DFT molecular orbital study (Figure 4), which has shown that both HOMO and LUMO of compound $\mathbf{1}$ are separated by a very large energy gap (103.1 kcal mol-1), have a large contribution from the $\mathrm{Br}$ atom, and that, as the LUMO contains a $\sigma$-antibonding overlap between $\mathrm{Mn}$ and $\mathrm{Br}$ with negligible contribution from the atoms of the germylene ligand, complex $\mathbf{1}$ is prone to break the $\mathrm{Mn}-\mathrm{Br}$ bond upon treatment with Lewis bases.

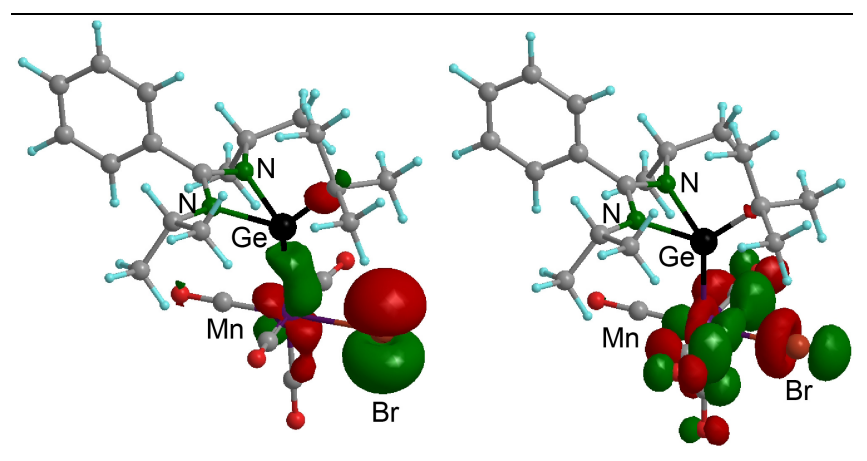

Figure 4. HOMO (left) and LUMO (right) of complex 1, shown at an isosurface value of \pm 0.05 .

Pursuing the synthesis of an elusive mononuclear complex containing a chelating 4electron-donor imine-germylene ligand, we decided to use AgOTf (OTf = triflate) as bromide abstractor because the triflate anion is a weakly-coordinating ligand and, in contrast to $\mathrm{Ag}\left[\mathrm{BF}_{4}\right]$, it has never been reported as a source of fluoride anions. In this case, a comparison of the analytical and spectroscopic data of the product obtained by treating complex 1 with AgOTf with those of complexes 1-3 (and a subsequent XRD study, see below) determined that the triflate complex is $\left[\mathrm{Mn}(\mathrm{OTf})\left\{\mathrm{Ge}\left({ }^{i} \mathrm{Pr}_{2} \text { bzam }\right)^{t} \mathrm{Bu}\right\}(\mathrm{CO})_{4}\right](4$; Scheme 1) and, therefore, that it arises from the simple substitution of the triflate for the bromide anion in 1. Additionally, trying to induce a Mn-to-Ge shift of the OTf group of $\mathbf{4}$, we heated this complex in toluene at $90{ }^{\circ} \mathrm{C}$, but an inseparable mixture was again obtained. 
Therefore, the results described above do not yet provide satisfactory answers to questions such as why and how do the reactions of $\mathbf{1}$ with $\mathrm{LiMe}$ or $\mathrm{Ag}\left[\mathrm{BF}_{4}\right]$ lead to compounds 2 and $\mathbf{3}$ or why imine-germanate derivatives analogous to $\mathbf{2}$ and $\mathbf{3}$ are not obtained from the reaction of 1 with AgOTf or from the thermolyses of $\mathbf{1}$ and 4. To shed more light on these questions, we are currently studying reactions of complex 1 with other inorganic and organic nucleophiles and performing mechanistic DFT calculations.

With the aim of completely determine the structure of triflate $\mathbf{4}$, a crystal obtained from a hexane solution of this complex was analyzed by XRD. It resulted to contain a 1:1 mixture of triflate 4 and a dimanganese(I) complex of formula $\left[\mathrm{Mn}_{2}\left\{\mu-\kappa^{4} G e_{2}, O_{2}-\mathrm{Ge}_{2}{ }^{t} \mathrm{Bu}_{2}(\mathrm{OH})_{2} \mathrm{O}\right\}(\mathrm{CO})_{8}\right]$ (5). While the molecular structure of 4 (Figure 5) was as it was expected, that of complex 5 was

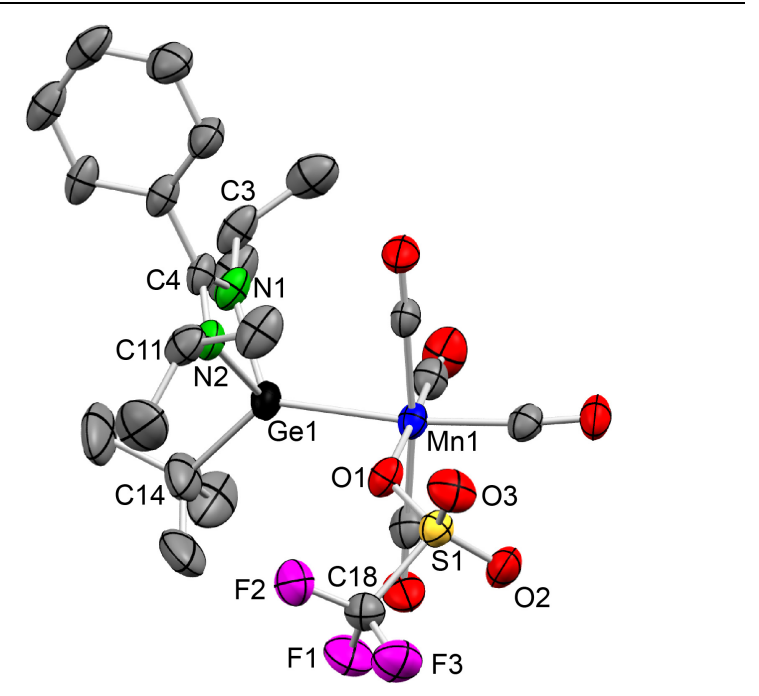

Figure 5. XRD molecular structure of $\mathbf{4}$ in $\mathbf{4 . 5}(35 \%$ displacement ellipsoids; $\mathrm{H}$ atoms omitted for clarity).

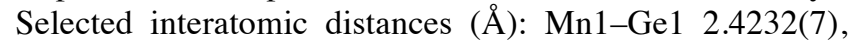
Mn1-O1 2.088(3), Ge1-C14 1.989(5), Ge1-N1 1.971(3), Ge1-N2 1.971(3), N1-C3 1.471(6), N1-C4 1.315(5), N2C4 1.324(5), S1-O1 1.461(3), S1-O2 1.423(3), S1-O3 $.421(3)$. The N2-C11 distance is not given because the C11 atom is involved in positional disorder.

very surprising (Figure 6), since it consists of two $\mathrm{Mn}(\mathrm{CO})_{4}$ fragments doubly bridged in cis coordination sites by an unprecedented digermanate(II) ligand, $\left[{ }^{t} \mathrm{Bu}(\mathrm{OH}) \mathrm{GeOGe}(\mathrm{OH})^{t} \mathrm{Bu}\right]^{2-}$, which comprises an $\mathrm{HOGeOGeOH}$ chain in which each Ge atom is also attached to a tert-butyl group. In the complex, each $\mathrm{Mn}$ atom is attached to a $\mathrm{Ge}$ atom and to the $\mathrm{O}$ atom of an $\mathrm{OH}$ group in such a way that the molecule has $C_{2}$ symmetry (non crystallographic), with the two-fold 
axis passing through the mid point of the $\mathrm{Mn}-\mathrm{Mn}$ segment and through the $\mathrm{O}$ atom that connects the two Ge atoms. In the crystals of $\mathbf{4 \cdot 5}$, both complexes are packed in chains in which each $\mathrm{OH}$ group is hydrogen-bonded to one of the two uncoordinated $\mathrm{O}$ atoms of the triflate ligand (Supporting Information, Figure SI-8).

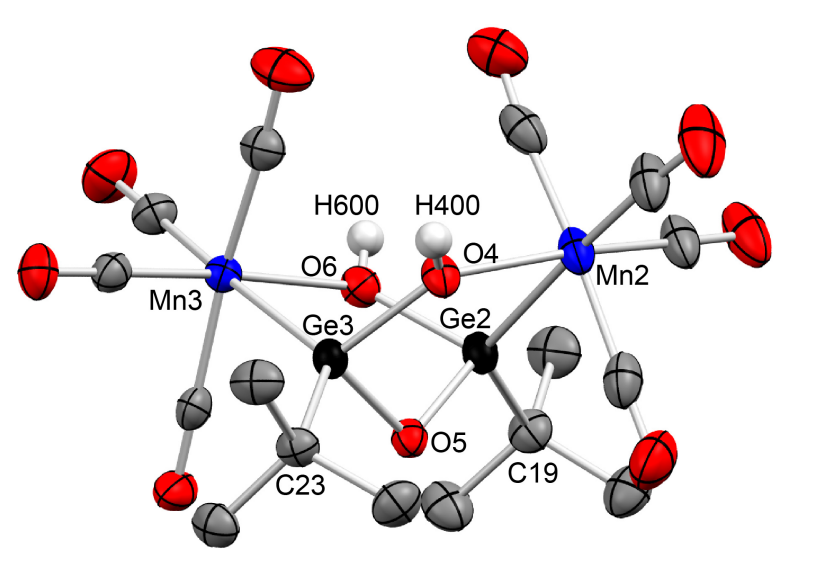

Figure 6. XRD molecular structure of $\mathbf{5}$ in $\mathbf{4 . 5}(35 \%$ displacement ellipsoids; $\mathrm{H}$ atoms, except those of the $\mathrm{OH}$ groups, omitted for clarity). Selected interatomic distances

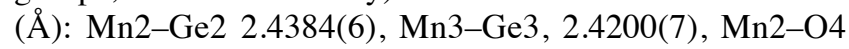
2.096(2), Mn3-O6 2.108(2), Ge2-O5 1.801(2), Ge2-O6 1.874(2), Ge3-O4 1.874(2), Ge3-O5 1.796(2), Ge2-C19 1.981(3), Ge3-C23 1.978(4), Ge2 $\cdots \mathrm{Ge} 3 \quad 2.902(2)$, Mn2 *Mn3 4.6995(1).

As complex $\mathbf{5}$ in the crystal of $\mathbf{4 . 5}$ clearly resulted from an adventitious hydrolysis of complex $\mathbf{4}$, we subsequently treated a toluene solution of the triflate complex $\mathbf{4}$ with water. This reaction immediately led to a 1:2 mixture of $\mathbf{5}$ and the amidinium salt $\left[{ }^{i} \operatorname{Pr}_{2}\right.$ bzamH $\left._{2}\right] \mathrm{OTf}(\mathbf{6})$ (Scheme 3), which were easily separated and isolated in high yields.

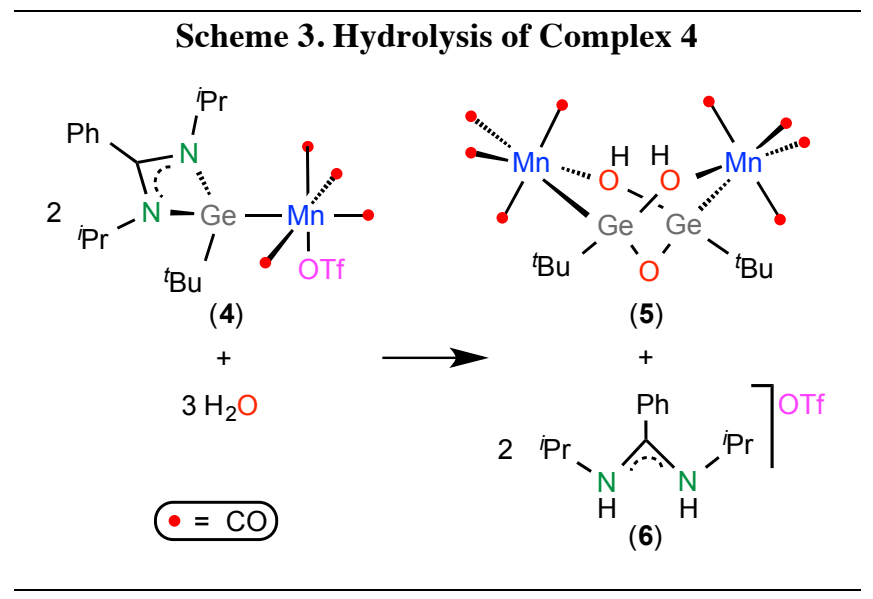


As expected from its symmetry, the ${ }^{1} \mathrm{H}$ and ${ }^{13} \mathrm{C}\left\{{ }^{1} \mathrm{H}\right\}$ NMR spectra of compound $\mathbf{5}$ are very simple, their most relevant feature being the low chemical shift of the $\mathrm{OH}$ proton resonance, $\delta_{\mathrm{H}}-0.91 \mathrm{ppm}$. The solid-state structure of the amidinium salt $\mathbf{6}$ was determined by XRD. In the crystal, cations and anions are connected to each other by hydrogen bonds that involve an amidinium NH group and a triflate O atom (Supporting Information, Figure SI-9).

Most of the hitherto known TM complexes equipped with oxo-, hydroxo-, or alkoxogermanate ligands result from oxidation, hydrolysis, or alcoholysis processes on TM complexes having Ge-donor ligands. ${ }^{4 \mathrm{i}, 11-13}$ As far as we are aware, only one hydrolysis of an amidinategermylene TM complex has been hitherto reported, namely, that of the rhodium(I) complex

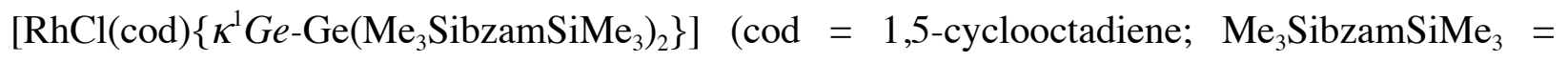
$N, N$ '-bis(trimethylsilyl)benzamidinate), which leads to the oxo-bridged-digermylene dirhodium(I) derivative $\left[\mathrm{Rh}_{2} \mathrm{Cl}_{2}(\mathrm{cod})_{2}\left\{\mu-\kappa^{2} G e, G e^{\prime}-\mathrm{Ge}_{2} \mathrm{O}\left(\mathrm{Me}_{3} \mathrm{SibzamSiMe}\right)_{2}\right\}\right]$, reported by Castel and co-workers. ${ }^{4 \mathrm{i}}$

\section{CONCLUSIONS}

In summary, this contribution, in addition to reporting the first amidinate-germylene derivatives of manganese ( $\mathbf{1}$ and $\mathbf{4}$ ), it also describes the unprecedented transformation of a terminal 2-electron-donor amidinate-germylene ligand (that of 1) into chelating 3-electron-donor $\kappa^{2}-N, G e$-imine-germanate ligands (those of $\mathbf{2}$ and 3 ). The instability of these amidinategermylene derivatives of manganese toward water has been established by isolating and characterizing compound $\mathbf{5}$, which contains a novel oxo-dihydroxo-digermanate(II) ligand bridging two manganese atoms.

On the other hand, the herein reported results provide additional data supporting that the coordination of one of the $\mathrm{N}$ atoms of amidinate-HTs to a TM is only a favorable process if the final product does not contain a three-coordinate HT donor atom. In fact, besides this work (complexes $\mathbf{2}$ and 3), such a ligand behavior has only been observed in (a) binuclear TM complexes where the HT donor atom is finally attached to four atoms (two TM atoms, an amidinate $\mathrm{N}$ atom, and an additional anionic group) (2b,2c,3g $^{2}$ and (b) bis(guanidinate)-silylenes in group-6 metal complexes, where the $\mathrm{Si}$ atom is surrounded by one metal atom and three amidinate $\mathrm{N}$ atoms. ${ }^{9}$ 
Given the strong interest that is currently being devoted to the coordination chemistry of HTs, it is expected that these results will have implications in future stoichiometric and catalytic reactions involving amidinate-HTs and TM complexes.

\section{EXPERIMENTAL SECTION}

General Procedures. Solvents were dried over appropriate desiccating reagents and were distilled under argon before use. All reactions were carried out under argon, using dry box and/or Schlenk-vacuum line techniques and were routinely monitored by solution IR spectroscopy. All reaction products were vacuum-dried for several hours prior to being weighted and analyzed. The germylene $\mathrm{Ge}\left({ }^{i} \operatorname{Pr}_{2}\right.$ bzam $) \mathrm{Cl}$ was prepared following a published procedure. ${ }^{3 \mathrm{~g}}$ All remaining reagents were purchased from commercial sources. NMR spectra were run on a Bruker DPX-300 instrument, using as standards a residual protic solvent resonance for ${ }^{1} \mathrm{H}$ $\left[\delta\left(\mathrm{C}_{6} H \mathrm{D}_{5}\right)=7.16 \mathrm{ppm} ;\left[\delta\left(\mathrm{CHCl}_{3}\right)=7.26 \mathrm{ppm}\right]\right.$, a solvent resonance for ${ }^{13} \mathrm{C}\left[\delta\left(C_{6} \mathrm{D}_{6}\right)=128.1\right.$ ppm; $\left[\delta\left(\mathrm{CHCl}_{3}\right)=77.16 \mathrm{ppm}\right]$, and an external solution of trifluoroacetic acid in $\mathrm{CDCl}_{3}$ for ${ }^{19} \mathrm{~F}$ $\left[\delta\left(\mathrm{CF}_{3} \mathrm{CO}_{2} \mathrm{H}\right)=-76.55 \mathrm{ppm}\right]$. Elemental analyses were obtained from a Perkin-Elmer 2400 microanalyzer. Mass spectra (MS) were run on a VG Autospec double-focusing mass spectrometer operating in the $\mathrm{FAB}+$ mode; ions were produced with a standard $\mathrm{Cs}^{+}$gun at about $30 \mathrm{kV}$; 3-nitrobenzyl alcohol was used as matrix; data given correspond to the most abundant isotopomer of the molecular ion or of the greatest mass fragment.

$\mathbf{G e}\left({ }^{i} \operatorname{Pr}_{2} \mathbf{b z a m}\right)^{t} \mathbf{B u}: \mathrm{Li}^{t} \mathrm{Bu}(5.8 \mathrm{~mL}, 1.7 \mathrm{M}$ in pentane, $9.9 \mathrm{mmol})$ was added to a solution of $\mathrm{Ge}\left({ }^{i} \mathrm{Pr}_{2}\right.$ bzam $) \mathrm{Cl}(3.04 \mathrm{~g}, 9.8 \mathrm{mmol})$ in diethylether $(30 \mathrm{~mL})$ at $-78{ }^{\circ} \mathrm{C}$. The resulting suspension was allowed to warm up to room temperature and then stirred for $6 \mathrm{~h}$. The solvent was removed under reduced pressure, the residue was extracted into hexane $(2 \times 30 \mathrm{~mL})$, and the filtrate was evaporated to dryness under vacuum to give $\operatorname{Ge}\left({ }^{i} \operatorname{Pr}_{2} \text { bzam }\right)^{t} \mathrm{Bu}$ as an orange oily material (2.78 g, $85 \%)$. ${ }^{1} \mathrm{H}$ NMR $\left(\mathrm{C}_{6} \mathrm{D}_{6}, 300.1 \mathrm{MHz}, 293 \mathrm{~K}\right)$ : $\delta$ 7.12-7.04 (m, $5 \mathrm{H}, 5 \mathrm{CH}$ of Ph), 3.39 (sept, $2 \mathrm{H}, J=6.4 \mathrm{~Hz}, 2 \mathrm{CH}$ of $2{ }^{i} \mathrm{Pr}$ ), 1.35 (s, $9 \mathrm{H}, 3 \mathrm{Me}$ of $\left.{ }^{t} \mathrm{Bu}\right), 1.09$ (d, $J=6.4 \mathrm{~Hz}, 6 \mathrm{H}, 2$ $M e$ of $\left.{ }^{i} \mathrm{Pr}\right), 0.95\left(\mathrm{~d}, J=6.4 \mathrm{~Hz}, 6 \mathrm{H}, 2 \mathrm{Me}\right.$ of $\left.{ }^{i} \mathrm{Pr}\right) \mathrm{ppm} .{ }^{13} \mathrm{C}\left\{{ }^{1} \mathrm{H}\right\} \mathrm{NMR}\left(\mathrm{C}_{6} \mathrm{D}_{6}, 75.5 \mathrm{MHz}, 293 \mathrm{~K}\right): \delta$ $165.7(\mathrm{NCN}), 131.9\left(C_{\text {ipso }}\right.$ of $\left.\mathrm{Ph}\right), 129.6$ (2 CH of Ph), 129.1 (2 $C \mathrm{H}$ of $\left.\mathrm{Ph}\right), 128.9(\mathrm{~s}, \mathrm{CH}$ of $\mathrm{Ph})$, 47.1 (2 $\mathrm{CH}$ of $\left.2{ }^{i} \mathrm{Pr}\right), 31.1\left(\mathrm{C}\right.$ of $\left.{ }^{t} \mathrm{Bu}\right), 27.6$ (3 $\mathrm{Me}$ of $\left.{ }^{\mathrm{t}} \mathrm{Bu}\right), 27.0$ (2 $\mathrm{Me}$ of $\left.{ }^{i} \mathrm{Pr}\right), 25.3$ (2 $\mathrm{Me}$ of $\left.{ }^{i} \mathrm{Pr}\right)$. 
$\left[\mathbf{M n B r}\left\{\mathbf{G e}\left({ }^{i} \operatorname{Pr}_{2} \mathbf{b z a m}\right)^{t} \mathbf{B u}\right\}(\mathbf{C O})_{4}\right]$ (1): A toluene solution of $\mathrm{Ge}\left({ }^{i} \operatorname{Pr}_{2} \text { bzam }\right)^{t} \mathrm{Bu}(0.20 \mathrm{~mL}$, $0.37 \mathrm{M}, 0.074 \mathrm{mmol})$ was added to a solution of $\left[\mathrm{MnBr}(\mathrm{CO})_{5}\right](20 \mathrm{mg}, 0.073 \mathrm{mmol})$ in toluene $(10 \mathrm{~mL})$. The initial yellow color changed to light orange. After stirring at room temperature for $10 \mathrm{~min}$, the solvent was removed under reduced pressure and the crude reaction mixture was separated by column chromatography on silica-gel $(2$ x $3 \mathrm{~cm})$. Hexane-dicholoromethane $(1: 2)$ eluted compound 1, which was isolated as a yellow solid (35 mg, $82 \%$ ). Anal. (\%) Calcd. for $\mathrm{C}_{21} \mathrm{H}_{28} \mathrm{BrGeMnN}_{2} \mathrm{O}_{4}(\mathrm{MW}=579.91 \mathrm{amu}): \mathrm{C}, 43.49 ; \mathrm{H}, 4.87 ; \mathrm{N}, 4.83$; found: 43.51; H, 4.89; N, 4.82. (+)-FAB MS: $m / z 580[M]^{+}$. IR (toluene): $v_{\mathrm{CO}} 2068(\mathrm{~m}), 2001(\mathrm{~m}), 1981(\mathrm{vs}), 1935(\mathrm{~m}) \mathrm{cm}^{-}$ 1. ${ }^{1} \mathrm{H}$ NMR $\left(\mathrm{C}_{6} \mathrm{D}_{6}, 300.1 \mathrm{MHz}, 293 \mathrm{~K}\right): \delta 7.22(\mathrm{~m}, 1 \mathrm{H}, \mathrm{CH}$ of Ph), 7.03-6.89 (m, $4 \mathrm{H}, 4 \mathrm{CH}$ of $\mathrm{Ph}$ ), 3.35 (sept, $J=6.6 \mathrm{~Hz}, 2 \mathrm{H}, 2 \mathrm{CH}$ of $\left.2{ }^{i} \mathrm{Pr}\right), 1.39\left(\mathrm{~s}, 9 \mathrm{H},{ }^{t} \mathrm{Bu}\right), 1.09(\mathrm{~d}, J=6.6 \mathrm{~Hz}, 6 \mathrm{H}, 2 \mathrm{Me}$ of $\left.{ }^{i} \operatorname{Pr}\right), 1.01\left(\mathrm{~d}, J=6.6 \mathrm{~Hz}, 6 \mathrm{H}, 2 \mathrm{Me}\right.$ of $\left.{ }^{i} \mathrm{Pr}\right) \mathrm{ppm} .{ }^{13} \mathrm{C}\left\{{ }^{1} \mathrm{H}\right\}$ NMR $\left(\mathrm{C}_{6} \mathrm{D}_{6}, 75.5 \mathrm{MHz}, 293 \mathrm{~K}\right): \delta$ 219.7 (CO), 215.7 (2 CO), $213.1(\mathrm{CO}), 171.8(\mathrm{NCN}), 130.5-127.3$ (5 CHs $+1 C_{\text {ipso }}$ of Ph), 48.1 (2 $\mathrm{CH}$ of $2^{i} \mathrm{Pr}$ ), $39.0\left(\mathrm{C}\right.$ of $\left.{ }^{t} \mathrm{Bu}\right), 27.0$ (3 Me of $\left.{ }^{t} \mathrm{Bu}\right), 24.9$ (2 $\mathrm{Me}$ of ${ }^{i} \mathrm{Pr}$ ), 23.7 (2 $\mathrm{Me}$ of ${ }^{i} \mathrm{Pr}$ ) ppm.

[Mn $\left.\left\{\boldsymbol{\kappa}^{2} \boldsymbol{G e}, \boldsymbol{N}-\mathrm{GeMe}\left({ }^{i} \operatorname{Pr}_{2} \mathbf{b z a m}\right)^{t} \mathrm{Bu}\right\}(\mathbf{C O})_{4}\right]$ (2): A toluene solution of $\operatorname{Ge}\left({ }^{i} \operatorname{Pr}_{2}\right.$ bzam ${ }^{t} \mathrm{Bu}$ $(0.20 \mathrm{~mL}, 0.37 \mathrm{M}, 0.074 \mathrm{mmol})$ was added to a solution of $\left[\mathrm{MnBr}(\mathrm{CO})_{5}\right](20 \mathrm{mg}, 0.073 \mathrm{mmol})$ in toluene $(10 \mathrm{~mL})$. The initial yellow color changed to light orange. After stirring at room temperature for $10 \mathrm{~min}$, LiMe ( $45 \mu \mathrm{L}, 1.6 \mathrm{M}$ in diethyl ether, $0.072 \mathrm{mmol}$ ) was added and the mixture was stirred at room temperature for $30 \mathrm{~min}$. The initial yellow color changed to orange. The solvent was removed under reduced pressure and the crude reaction mixture was separated by column chromatography on silica-gel $(2 \times 3 \mathrm{~cm})$. Dichloromethane eluted compound $\mathbf{2}$, which was isolated as a light yellow solid (20 mg, $53 \%$ ). Anal. (\%) Calcd. for $\mathrm{C}_{22} \mathrm{H}_{31} \mathrm{GeMnN}_{2} \mathrm{O}_{4}$ $(\mathrm{MW}=515.04 \mathrm{amu}): \mathrm{C}, 51.30 ; \mathrm{H}, 6.07 ; \mathrm{N}, 5.44$; found: $\mathrm{C}, 51.42 ; \mathrm{H}, 6.12 ; \mathrm{N}, 5.83$. (+)-FAB MS: $m / z 516[M]^{+}$. IR (toluene): $v_{\mathrm{CO}} 2063(\mathrm{w}), 1984(\mathrm{vs}), 1965(\mathrm{~m}), 1940(\mathrm{~m}) \mathrm{cm}^{-1} .{ }^{1} \mathrm{H}$ NMR $\left(\mathrm{C}_{6} \mathrm{D}_{6}, 300.1 \mathrm{MHz}, 293 \mathrm{~K}\right): \delta$ 6.94-6.89 (m, $3 \mathrm{H}, 3 \mathrm{CH}$ of Ph), 6.76-6.66 (m, $2 \mathrm{H}, 2 \mathrm{CH}$ of Ph), 3.40-3.25 (m, $2 \mathrm{H}, 2 \mathrm{CH}$ of $\left.2{ }^{i} \mathrm{Pr}\right), 1.30$ (s, $\left.9 \mathrm{H},{ }^{t} \mathrm{Bu}\right), 1.01$ (d, $J=6.5 \mathrm{~Hz}, 3 \mathrm{H}$, Me of ${ }^{i} \mathrm{Pr}$ ), 0.96 (s, $3 \mathrm{H}, \mathrm{Ge}-\mathrm{Me})$ 0.90-0.86 (m, $6 \mathrm{H}, 2 \mathrm{Me}$ of $\left.{ }^{i} \mathrm{Pr}\right), 0.57\left(\mathrm{~d}, J=6.5 \mathrm{~Hz}, 3 \mathrm{H}, \mathrm{Me}\right.$ of $\left.{ }^{i} \mathrm{Pr}\right) \mathrm{ppm} .{ }^{13} \mathrm{C}\left\{{ }^{1} \mathrm{H}\right\}$ NMR ( $\left.\mathrm{C}_{6} \mathrm{D}_{6}, 75.5 \mathrm{MHz}, 293 \mathrm{~K}\right): \delta 173.7(\mathrm{NCN}), 138.5\left(C_{i p s o}\right.$ of Ph), 128.7-127.0 (5 CHs of Ph), $54.4\left(\mathrm{CH}\right.$ of ${ }^{i} \mathrm{Pr}$ ), $51.3\left(\mathrm{CH}\right.$ of ${ }^{i} \mathrm{Pr}$ ), $31.4\left(\mathrm{C}\right.$ of ${ }^{t} \mathrm{Bu}$ ), 28.3 (3 $\mathrm{Me}$ of ${ }^{t} \mathrm{Bu}$ ), 24.6 ( $\mathrm{Me}$ of $\mathrm{Ge}-\mathrm{Me}$ and 2 Me of ${ }^{i} \mathrm{Pr}$ ), 24.4 (Me of $\left.{ }^{i} \mathrm{Pr}\right), 22.2\left(\mathrm{Me}\right.$ of $\left.{ }^{i} \mathrm{Pr}\right) \mathrm{ppm}$.

[Mn $\left.\left\{\boldsymbol{\kappa}^{2} \boldsymbol{G e}, \boldsymbol{N}-\mathbf{G e F}\left({ }^{i} \operatorname{Pr}_{2} \text { bzam }\right)^{t} \mathrm{Bu}\right\}(\mathbf{C O})_{4}\right]$ (3): A toluene solution of $\mathrm{Ge}\left({ }^{i} \operatorname{Pr}_{2} \text { bzam }\right)^{t} \mathrm{Bu}$ $(0.20 \mathrm{~mL}, 0.37 \mathrm{M}, 0.074 \mathrm{mmol})$ was added to a solution of $\left[\mathrm{MnBr}(\mathrm{CO})_{5}\right](20 \mathrm{mg}, 0.073 \mathrm{mmol})$ 
in toluene $(10 \mathrm{~mL})$. The initial yellow color changed to light orange. After stirring at room temperature for $10 \mathrm{~min}$, solid $\mathrm{Ag}\left[\mathrm{BF}_{4}\right](15 \mathrm{mg}, 0.074 \mathrm{mmol})$ was added and the mixture was stirred at room temperature for $2 \mathrm{~h}$. The initial yellow solution changed to dark brown suspension. The solvent was removed under reduced pressure and the crude reaction mixture was separated by column chromatography on silica-gel $(2 \times 3 \mathrm{~cm})$. THF eluted compound $\mathbf{3}$, which was isolated as a light yellow solid (31 mg, $82 \%$ ). Anal. (\%) Calcd. for $\mathrm{C}_{21} \mathrm{H}_{28} \mathrm{FGeMnN}_{2} \mathrm{O}_{4}(\mathrm{MW}=519.00 \mathrm{amu}): \mathrm{C}, 48.60 ; \mathrm{H}, 5.44 ; \mathrm{N}, 5.40$; found: $\mathrm{C}$, 48.65; H, 5.47; N, 5.38. (+)-FAB MS: $m / z 408$ [M-3 CO] $]^{+}$IR (toluene): $v_{\mathrm{CO}} 2063(\mathrm{w}), 1984$ (vs), 1965 (m), $1940(\mathrm{~m}) \mathrm{cm}^{-1} .{ }^{1} \mathrm{H}$ NMR $\left(\mathrm{C}_{6} \mathrm{D}_{6}, 300.1 \mathrm{MHz}, 293 \mathrm{~K}\right): \delta 6.93$ (m, $3 \mathrm{H}, 3 \mathrm{CH}$ of Ph), 6.68-6.60 (m, $2 \mathrm{H}, 2 \mathrm{CH}$ of $\mathrm{Ph}$ ), 3.65-3.57 (m, $1 \mathrm{H}, \mathrm{CH}$ of ${ }^{i} \mathrm{Pr}$ ), 3.36-3.27 (m, $1 \mathrm{H}, \mathrm{CH}$ of $\left.{ }^{i} \mathrm{Pr}\right), 1.43$ (s, $9 \mathrm{H}$, $\left.{ }^{t} \mathrm{Bu}\right), 1.06\left(\mathrm{~d}, J=6.6 \mathrm{~Hz}, 3 \mathrm{H}, \mathrm{Me}\right.$ of $\left.{ }^{i} \mathrm{Pr}\right), 0.90-0.87$ (m, $9 \mathrm{H}, 3 \mathrm{Me}$ of $\left.{ }^{i} \mathrm{Pr}\right) \mathrm{ppm} .{ }^{13} \mathrm{C}\left\{{ }^{1} \mathrm{H}\right\} \mathrm{NMR}$ $\left(\mathrm{C}_{6} \mathrm{D}_{6}, 75.5 \mathrm{MHz}, 293 \mathrm{~K}\right): \delta 174.6(\mathrm{NCN}), 137.63$ ( $C_{i p s o}$ of $\left.\mathrm{Ph}\right), 129.0-126.9$ (5 CHs of $\mathrm{Ph}$ ), 55.0 $\left(\mathrm{CH}\right.$ of $\left.{ }^{i} \mathrm{Pr}\right), 50.9\left(\mathrm{CH}\right.$ of $\left.{ }^{i} \mathrm{Pr}\right), 37.9\left(\mathrm{~d}, J=12.5 \mathrm{~Hz}, C\right.$ of $\left.{ }^{t} \mathrm{Bu}\right), 27.7\left(3 \mathrm{Me}\right.$ of $\left.{ }^{t} \mathrm{Bu}\right), 24.5$ (Me of ${ }^{i} \mathrm{Pr}$ ), 24.3 (Me of ${ }^{i} \mathrm{Pr}$ ), 24.2 (Me of ${ }^{i} \mathrm{Pr}$ ), 22.1 (Me of ${ }^{i} \mathrm{Pr}$ ) ppm. ${ }^{19} \mathrm{~F}\left\{{ }^{1} \mathrm{H}\right\}$ NMR $\left(\mathrm{C}_{6} \mathrm{D}_{6}, 282.4 \mathrm{MHz}\right.$, $293 \mathrm{~K}): \delta-168.4$ (s) ppm.

[Mn(OTf) $\left.\left\{\mathbf{G e}\left({ }^{i} \operatorname{Pr}_{2} \mathbf{b z a m}\right)^{t} \mathbf{B u}\right\}(\mathbf{C O})_{4}\right]$ (4): A toluene solution of $\operatorname{Ge}\left({ }^{i} \operatorname{Pr}_{2} \mathrm{bzam}\right)^{t} \mathrm{Bu}(0.20$ $\mathrm{mL}, 0.37 \mathrm{M}, 0.074 \mathrm{mmol})$ was added to a solution of $\left[\mathrm{MnBr}(\mathrm{CO})_{5}\right](20 \mathrm{mg}, 0.073 \mathrm{mmol})$ in toluene $(10 \mathrm{~mL})$. After stirring at room temperature for $10 \mathrm{~min}$, solid AgOTf (40 mg, 0.156 $\mathrm{mmol}$ ) was added and the mixture was stirred at room temperature for $20 \mathrm{~min}$. The initial yellow solution changed to dark brown suspension. The solvent was removed under reduced pressure and the crude reaction mixture was extracted into hexane $(2 \times 5 \mathrm{~mL})$. The filtered extract was evaporated to dryness under vacuum to give 4 as a yellow solid (36 mg, $76 \%$ ). Anal. (\%) Calcd. for $\mathrm{C}_{22} \mathrm{H}_{28} \mathrm{~F}_{3} \mathrm{GeMnN}_{2} \mathrm{O}_{7} \mathrm{~S}(\mathrm{MW}=649.08 \mathrm{amu})$ : C, 40.71; H, 4.34; N, 4.32; found: $\mathrm{C}, 40.76 ; \mathrm{H}$, 4.37; N, 4.30. IR (toluene): $v_{\mathrm{CO}} 2087$ (m), 2022 (m), 1998 (vs), 1947 (m). ${ }^{1} \mathrm{H}$ NMR ( $\mathrm{C}_{6} \mathrm{D}_{6}, 300.1$ MHz, $293 \mathrm{~K}$ ): $\delta 7.34$ (m, $1 \mathrm{H}, \mathrm{CH}$ of Ph), 7.11-6.90 (m, $4 \mathrm{H}, 4 \mathrm{CH}$ of Ph), 3.29 (sept, $J=6.5$ $\mathrm{Hz}, 2 \mathrm{H}, 2 \mathrm{CH}$ of $2{ }^{i} \mathrm{Pr}$ ), 1.30 (s, $9 \mathrm{H},{ }^{t} \mathrm{Bu}$ ), 0.98 (d, J=6.5 Hz, $6 \mathrm{H}, 2 \mathrm{Me}$ of ${ }^{i} \mathrm{Pr}$ ), 0.87 (d, J = 6.6 $\mathrm{Hz}, 6 \mathrm{H}, 2 \mathrm{Me}$ of $\left.{ }^{i} \mathrm{Pr}\right) \mathrm{ppm} .{ }^{19} \mathrm{~F}\left\{{ }^{1} \mathrm{H}\right\}$ NMR $\left(\mathrm{C}_{6} \mathrm{D}_{6}, 282.4 \mathrm{MHz}, 293 \mathrm{~K}\right): \delta-76.1$ (s) ppm. ${ }^{13} \mathrm{C}\left\{{ }^{1} \mathrm{H}\right\}$ NMR ( $\left.\mathrm{C}_{6} \mathrm{D}_{6}, 75.5 \mathrm{MHz}, 293 \mathrm{~K}\right): \delta 218.1(\mathrm{CO}), 214.6(2 \mathrm{CO}), 210.0(\mathrm{CO}), 173.0(\mathrm{NCN})$, 131.0-127.7 (C + 5 CHs of Ph), 120.3 (q, $\left.J=319 \mathrm{~Hz}, C \mathrm{~F}_{3}\right) .47 .9$ (2 CH of $2{ }^{i} \mathrm{Pr}$ ), 39.3 ( $C$ of $\left.{ }^{t} \mathrm{Bu}\right), 26.2$ (3 Me of $\left.{ }^{t} \mathrm{Bu}\right), 24.7$ (2 $\mathrm{Me}$ of $\left.{ }^{i} \mathrm{Pr}\right), 23.8$ (2 $\mathrm{Me}$ of $\left.{ }^{i} \mathrm{Pr}\right)$. 
$\left[\mathrm{Mn}_{2}\left\{\mu-\kappa^{4} \mathrm{Ge}_{2}, \mathrm{O}_{2}-\mathrm{Ge}_{2}{ }^{t} \mathrm{Bu}_{2}(\mathrm{OH})_{2} \mathrm{O}\right\}(\mathrm{CO})_{8}\right](5)$ and $\left[{ }^{i} \operatorname{Pr}_{2} \mathrm{bzamH}_{2}\right] \mathrm{OTf}(6)$ : Water $(5 \mu \mathrm{L}$, $0.277 \mathrm{mmol})$ was added to a toluene $(8 \mathrm{~mL})$ solution of $4(45 \mathrm{mg}, 0.070 \mathrm{mmol})$ and the mixture was stirred at room temperature for $60 \mathrm{~min}$. The initial yellow color changed to light orange. The solvent was removed under reduced pressure and the crude reaction mixture was extracted into hexane $(2 \times 5 \mathrm{~mL})$. The hexane solution was separated from a white solid by filtatrion. The filtrate was evaporated to dryness under vacuum to give compound 5 as a yellow solid (19 mg, $84 \%)$. The white solid was identified as $\left[{ }^{i} \mathrm{Pr}_{2}\right.$ bzamH $\left._{2}\right] \mathrm{OTf}(6)(22 \mathrm{mg}, 88 \%)$. Data for 5: Anal. Calcd. for $\mathrm{C}_{16} \mathrm{H}_{20} \mathrm{Ge}_{2} \mathrm{Mn}_{2} \mathrm{O}_{11}$ (MW = $643.42 \mathrm{amu}$ ): C, 29.87; H, 3.13; found: $\mathrm{C}, 30.01 ; \mathrm{H}, 3.19$. (+)-FAB MS: $m / z=644[M]^{+}$. IR (toluene): $v_{\mathrm{CO}} 2064(\mathrm{~m}), 1991$ (vs), $1969(\mathrm{~m}), 1933(\mathrm{~m}) \mathrm{cm}^{-1}$. ${ }^{1} \mathrm{H}$ NMR $\left(\mathrm{C}_{6} \mathrm{D}_{6}, 300.1 \mathrm{MHz}, 293 \mathrm{~K}\right): \delta 1.10\left(\mathrm{~s}, 18 \mathrm{H}, 2{ }^{\mathrm{t}} \mathrm{Bu}\right),-0.91(\mathrm{~s}, 2 \mathrm{H}, 2 \mathrm{OH}) \mathrm{ppm} .{ }^{13} \mathrm{C}\left\{{ }^{1} \mathrm{H}\right\}$ NMR ( $\left.\mathrm{C}_{6} \mathrm{D}_{6}, 75.5 \mathrm{MHz}, 293 \mathrm{~K}\right)$ : $\delta 219.9(\mathrm{COs}), 37.8\left(\mathrm{C}\right.$ of $\left.{ }^{t} \mathrm{Bu}\right), 25.9\left(6 \mathrm{Me}\right.$ of $\left.{ }^{t} \mathrm{Bu}\right) \mathrm{ppm}$. Data for 6: Anal. (\%) Calcd. for $\mathrm{C}_{14} \mathrm{H}_{21} \mathrm{~F}_{3} \mathrm{~N}_{2} \mathrm{O}_{3} \mathrm{~S}$ (MW = $354.39 \mathrm{amu}$ ): $\mathrm{C}, 47.45 ; \mathrm{H}, 5.97 ; \mathrm{N}, 7.91$; found: C, 47.51; H, 7.94; N, 7.87. (+)-FAB MS: $m / z=205.2\left[{ }^{i} \mathrm{Pr}_{2} \mathrm{bzamH}_{2}\right]^{+} .{ }^{1} \mathrm{H}$ NMR $\left(\mathrm{CDCl}_{3}\right.$, $300.1 \mathrm{MHz}, 293 \mathrm{~K}$ ): $\delta 8.90$ (s, br, 2 H, $2 \mathrm{NH}$ ), 7.66-7.35 (m, 5 H, $5 \mathrm{CH}$ of Ph), 3.25 (m, $2 \mathrm{H}, 2$ $\mathrm{CH}$ of ${ }^{i} \mathrm{Pr}$ ), 1.18 (s, br, $12 \mathrm{H}, 4 \mathrm{Me}$ of ${ }^{i} \mathrm{Pr}$ ) ppm. ${ }^{19} \mathrm{~F}\left\{{ }^{1} \mathrm{H}\right\}$ NMR $\left(\mathrm{C}_{6} \mathrm{D}_{6}, 282.4 \mathrm{MHz}, 293 \mathrm{~K}\right): \delta=$ -78.4 (s) ppm. ${ }^{13} \mathrm{C}\left\{{ }^{1} \mathrm{H}\right\} \mathrm{NMR}\left(\mathrm{CDCl}_{3}, 75.5 \mathrm{MHz}, 293 \mathrm{~K}\right): \delta 164.4(\mathrm{NCN}), 132.4(\mathrm{CH}$ of $\mathrm{Ph})$, 130.2 (2 CH of Ph), 126.6 (2 CH of Ph), $126.0\left(C_{i p s o}\right.$ of $\left.\mathrm{Ph}\right), 48.3$ (2 CH of $\left.{ }^{i} \mathrm{Pr}\right), 22.9$ (4 Me of ${ }^{i} \mathrm{Pr}$ ) ppm.

X-Ray Diffraction Analyses: Diffraction data were collected on an Oxford Diffraction Xcalibur Onyx Nova (1, 3, 4.5, and 6) and an Xcalibur Ruby Gemini (2) single crystal diffractometers. Empirical absorption corrections were applied using the SCALE3 ABSPACK algorithm as implemented in CrysAlisPro $\operatorname{RED}^{14}$ (for $\mathbf{1}, \mathbf{3}, \mathbf{4} \cdot \mathbf{5}$, and $\mathbf{6}$ ) and XABS2 ${ }^{15}$ (for 2). The structures were solved using SIR-97. ${ }^{16}$ Isotropic and full matrix anisotropic least square refinements were carried out using SHELXL. ${ }^{17}$ The hydrogen atoms of the $\mathrm{OH}(\mathrm{H} 400, \mathrm{H} 600$ in 5) and $\mathrm{NH}$ (H100, H200 in 6) groups were located in their corresponding Fourier maps. The remaining hydrogen atoms of all the compounds were set in calculated positions and refined riding on their parent atoms. The crystals of $\mathbf{1}$ and $\mathbf{2}$ were racemic twins and were refined using the TWIN order. The crystal of $\mathbf{1}$ was found to contain four symmetry-independent but analogous molecules in the asymmetric unit, each molecule exhibiting some positional disorder involving the $\mathrm{Br}$ atom and an adjacent $\mathrm{CO}$ ligand cis to the germylene ligand. This two ligands exchange their positions with occupancy ratios of $96: 4,83: 17,78: 22$, and 81:19, respectively, for 
molecules $1,2,3$, and 4, the greater occupancy corresponding to a situation in which the $\mathrm{Br}$ atom is aligned syn to the ${ }^{t} \mathrm{Bu}$ group. Restraints on the thermal and geometrical parameters of the atoms involved in this positional disorder were applied. For 2, restraints on the thermal parameters of the methyl carbon atoms of the tert-butyl group were required due to their tendency to give nonpositive definite ellipsoids. In the crystal of $\mathbf{4 \cdot 5}$, the iso-propyl group attached to the N2 atom of $\mathbf{4}$ was found disordered over two positions with an occupancy ratio of 74:26; restraints were applied on the thermal and geometrical parameters of the atoms involved. The WINGX program system ${ }^{18}$ was used throughout the structure determinations. The molecular plots were made with MERCURY. ${ }^{19}$ A selection of measurement and refinement data is given in Table SI-1. CCDC deposition numbers: 1008617 (1), 1008618 (2), 1008619 (3), 1012976 (4 -5), and 1012977 (6).

Computational Details: DFT calculations were carried out using the Becke's 3parameter hybrid exchange-correlation functional ${ }^{20}$ and the hybrid B3LYP nonlocal gradient correction. ${ }^{21}$ The LanL2DZ basis set, ${ }^{22}$ with relativistic effective core potentials, was used for the Mn atom. The basis set used for the remaining atoms was the $6-31 \mathrm{G}(\mathrm{d}, \mathrm{p}) .{ }^{23}$ The optimized structure of complex 1 was confirmed as an energy minimum by analytical calculation of frequencies (all positive eigenvalues). The corresponding cartesian coordinates are given in the Supporting Information (Table SI-2). Molecular orbital data were obtained from the natural bond order (NBO) analysis of the data. ${ }^{24}$ All calculations were carried out without symmetry constraints employing the Gaussian09 package. ${ }^{25}$

\section{ASSOCIATED CONTENT}

Supporting Information. Crystal, acquisition, and refinement XRD data, DFT-calculated atomic coordinates, ${ }^{1} \mathrm{H}$ and ${ }^{13} \mathrm{C}\left\{{ }^{1} \mathrm{H}\right\}$ NMR spectra, and X-ray crystallographic data in CIF format. This material is available free of charge via the Internet at http://pubs.acs.org.

\section{AUTHOR INFORMATION}

\section{Corresponding Authors}

*E-mails: jac@uniovi.es (J.A.C.), pga@uniovi.es (P.G.A.).

\section{Author Contributions}


The manuscript was written through contributions of all authors. All authors have given approval to the final version of the manuscript.

\section{Notes}

The authors declare no competing financial interest.

\section{ACKNOWLEDGMENTS}

This work has been supported by a European Union Marie Curie reintegration grant (FP7-2010RG-268329) and by Spanish MINECO-FEDER research grants (CTQ2010-14933, MAT201015094, DELACIERVA-09-05, and RYC-2012-10491).

\section{REFERENCES}

(1) For recent reviews on chemistry and/or catalysis of amidinate-HT-TM complexes, see: (a) Blom, B.; Gallego, D.; Driess, M. Inorg. Chem. Front. 2014, 1, 134. (b) Blom, B.; Stoelzel, M.;

Driess, M. Chem. Eur. J. 2013, 19, 40. (c) Asay, M.; Jones, C.; Driess, M. Chem. Rev. 2011, 111,354 .

(2) (a) Tan, G.; Blom, B.; Gallego, G.; Driess, M. Organometallics 2014, 33, 363. (b) Cabeza, J. A.; García-Álvarez, P.; Pérez-Carreño, E.; Polo, D. Chem. Eur. J. 2014, 20, 8654. (c) Cabeza, J. A.; Fernández-Colinas, J. M.; García-Álvarez, P.; Polo, D. RSC Adv. 2014, 4, 31503.

(3) (a) Gallego, D.; Brück, A.; Irran, E.; Meier, F.; Kaupp, M.; Driess, M.; Hartwig, J. F. J. Am. Chem. Soc. 2013, 135, 15617. (b) Blom, B.; Enthaler, S.; Inoue, S.; Irran, E.; Driess, M. J. Am. Chem. Soc. 2013, 135, 6703. (c) Breit, N. C.; Szilvási, T.; Suzuki, T.; Gallego, D.; Inoue, S. J. Am. Chem. Soc. 2013, 135, 17958. (d) Junold, K.; Baus, J. A.; Burschka, C.; Vent-Schmidt, T.; Riedel, S.; Tacke, R. Inorg. Chem. 2013, 52, 11593. (e) Azhakar, R.; Ghadwal, R. S.; Roesky, H. W.; Hey, J.; Krause, L.; Stalke, D. Dalton. Trans. 2013, 42, 10277. (f) Someya, C. I.; Haberberger, M.; Wang, W.; Enthaler, S.; Inoue, S. Chem. Let. 2013, 42, 286. (g) Cabeza, J. A.; García-Álvarez, P.; Polo, D. Dalton. Trans. 2013, 42, 1329.

(4) (a) Wang, W.; Inoue, S.; Enthaler, S.; Driess, M. Angew. Chem. Int. Ed. 2012, 51, 6167. (b) Brück, A.; Gallego, D.; Wang, W.; Irran, E.; Driess, M.; Hartwig, J. F. Angew. Chem. Int. Ed. 2012, 51, 11478. (c) Blom, B.; Driess, M.; Gallego, D.; Inoue, S. Chem. Eur. J. 2012, 18, 13355. (d) Azhakar, R.; Ghadwal, R. S.; Roesky, H. W.; Hey, J. Stalke, D. Chem. Asian. J. 2012, 7, 528. 
(e) Azhakar, R.; Ghadwal, R. S.; Roesky, H. W.; Wolf, H.; Stalke, D. J. Am. Chem. Soc. 2012, 134, 2423. (f) Junold, K.; Baus, J. A.; Burschka, C.; Tacke, R. Angew. Chem. Int. Ed. 2012, 51, 7020. (g) Azhakar, R.; Roesky, H. W.; Holstein, J. J.; Dittrich, B. Dalton. Trans. 2012, 41, 12096. (h) Wang, W.; Inoue, S.; Irran, E.; Driess, M. Angew. Chem. Int. Ed. 2012, 51, 3691. (i) Matioszek, D.; Saffon, N.; Sotiropoulos, J.-M.; Miqueu, K.; Castel, A.; Escudié, J. Inorg. Chem. 2012, 51, 11716.

(5) Azhakar, R.; Sarish, S. P.; Roesky, H. W.; Hey, J.; Stalke, D. Inorg. Chem. 2011, 50, 5039.

(6) (a) Tavčar, G.; Sen, S. S.; Azhakar, R.; Thorn, A.; Roesky, H. W. Inorg. Chem. 2010, 49, 10199. (b) Wang, W.; Inoue, S.; Yao, S.; Driess, M. J. Am. Chem. Soc. 2010, 132, 15890. (c) Matioszek, D.; Katir, N.; Saffon, N.; Castel, A. Organometallics 2010, 29, 3039. (d) Sen, S. S.; Kritzler-Kosch, M. P.; Nagendran, S.; Roesky, H. W.; Beck, T.; Pal, A.; Herbst-Irmer, R. Eur. J. Inorg. Chem. 2010, 5304. (e) Sen, S. S.; Kratzer, D.; Stern, D.; Roesky H. W.; Stalke, D. Inorg. Chem. 2010, 49, 5786.

(7) Yang, W.; Fu, H.; Wang, H.; Chen, M.; Ding, Y.; Roesky, H. W.; Jana, A. Inorg. Chem. 2009, 48,5058 .

(8) Jones, C.; Rose, R. P.; Stasch, A. Dalton Trans. 2008, 2871.

(9) Mück, F. M.; Kloss, D.; Baus, J. A.; Burschka, C.; Tacke, R. Chem. Eur. J. 2014, 20, in press. DOI: $10.1002 /$ chem.201402889.

(10) See, for example: (a) Reger, D. L.; Watson, R. P.; Gardinier, J. R.; Smith, M. D.; Pellechia, P. J. Inorg. Chem. 2006, 45, 10088 and ref. therein. (b) Coleman, K. S.; Fawcett, J.; Harding, D. A. J.; Hope, E. J.; Singh, K.; Solan, G. A. Eur. J. Inorg. Chem. 2010, 4310 and ref. therein.

(11) (a) Huang, M.; Kireenko, M. M.; Djevakov, P. B.; Zaitsev, K. V.; Oprunenko, Y. F.; Churakov, A. V.; Tyurin, D. A.; Karlov, S. S.; Zaitseva, G. S. J. Organomet. Chem. 2013, 735, 15. (b) Greene, J.; Curtis, M. D. Inorg. Chem. 1978, 17, 2324.

(12) (a) Adams, R. D.; Trufan, E. Organometallics 2010, 29, 4346. (b) Adams, R. D.; Captain, B.; Hollandsworth, C. B.; Johansson, M.; Smith, J. L., Jr. Organometallics 2006, 25, 3848. (c) 
Renner, G.; Huttner, G.; Rutsch, P. Z. Naturforsch. B, Chem. Sci. 2001, 56, 1328. (d) Filippou, A. C.; Steck, R.; Kociok-Kohn, G. J. Chem. Soc., Dalton Trans. 1999, 2267. (e) Adams, R. D.; Cotton, F. A.; Frenz, B. A. J. Organomet. Chem. 1974, 73, 93.

(13) Knoth, W. H. J. Am. Chem. Soc. 1979, 101, 2211.

(14) CrysAlisPro RED, version 1.171.34.36: Oxford Diffraction Ltd.: Oxford, UK, 2010.

(15) Parkin, S.; Moezzi, B.; Hope, H. J. Appl. Cryst. 1995, 28, 53.

(16) Altomare, A.; Burla, M. C.; Camalli, M.; Cascarano, G. L.; Giacovazzo, C.; Guagliardi, A.; Moliterni, A. G. C.; Polidori, G.; Spagna, R. J. Appl. Crystallogr. 1999, 32, 115.

(17) SHELXL: Sheldrick, G. M. Acta Crystallogr. 2008, A64, 112.

(18) WINGX, version 1.80.05 (2009): Farrugia, L. J. J. Appl. Crystallogr. 1999, 32, 837.

(19) MERCURY, CSD 3.1 (build RC5): Cambridge Crystallographic Data Centre, 2013.

(20) Becke, A. D. J. Chem. Phys. 1993, 98, 5648.

(21) Lee, C.; Yang, W.; Parr, R. G. Phys. Rev. B 1988, 37, 785.

(22) Hay, P. J.; Wadt, W. R. J. Chem. Phys. 1985, 82, 299.

(23) Hariharan, P. C.; Pople, J. A. Theor. Chim. Acta 1973, 28, 213.

(24) (a) Reed, A. E.; Weinstock, R. B.; Weinhold, F. J. Chem. Phys. 1985, 83, 735. (b) Reed, A. E.; Curtis, L. A.; Weinhold, F. Chem. Rev. 1988, 88, 899.

(25) Frisch, M. J.; Trucks, G. W.; Schlegel, H. B.; Scuseria, G. E.; Robb, M. A.; Cheeseman, J. R.; Scalmani, G.; Barone, V.; Mennucci, B.; Petersson, G. A.; Nakatsuji, H.; Caricato, M.; Li, X.; Hratchian, H. P.; Izmaylov, A. F.; Bloino, J.; Zheng, G.; Sonnenberg, J. L.; Hada, M.; Ehara, M.; Toyota, K.; Fukuda, R.; Hasegawa, J.; Ishida, M.; Nakajima, T.; Honda, Y.; Kitao, O.; Nakai, H.; Vreven, T.; Montgomery, J. A., Jr.; Peralta, J. E.; Ogliaro, F.; Bearpark, M.; Heyd, J. J.; Brothers, E.; Kudin, K. N.; Staroverov, V. N.; Kobayashi, R.; Normand, J.; Raghavachari, K.; 
Rendell, A.; Burant, J. C.; Iyengar, S. S.; Tomasi, J.; Cossi, M.; Rega, N.; Millam, N. J.; Klene, M.; Knox, J. E.; Cross, J. B.; Bakken, V.; Adamo, C.; Jaramillo, J.; Gomperts, R.; Stratmann, R. E.; Yazyev, O.; Austin, A. J.; Cammi, R.; Pomelli, C.; Ochterski, J. W.; Martin, R. L.; Morokuma, K.; Zakrzewski, V. G.; Voth, G. A.; Salvador, P.; Dannenberg, J. J.; Dapprich, S.; Daniels, A. D.; Farkas, Ö.; Foresman, J. B.; Ortiz, J. V.; Cioslowski, J.; Fox, D. J. Gaussian 09, revision A.01; Gaussian, Inc.: Wallingford, CT, 2009. 


\section{SYNOPSIS PARAGRAPH}

Manganese complexes containing 3-electron-donor imine-germanate ligands have been prepared from a manganese precursor containing a terminal 2-electron-donor amidinategermylene ligand.

SYNOPSIS AND ABSTRACT GRAPHIC

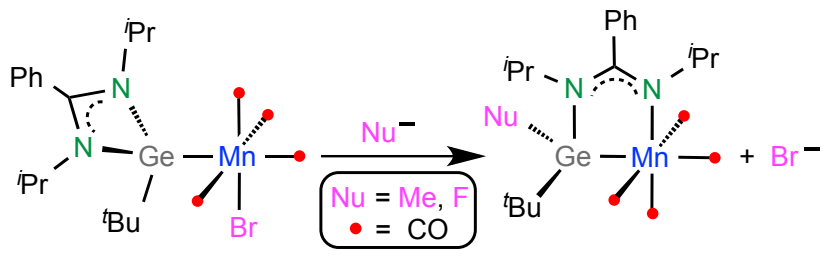

